\title{
POMIARY XRMI W UTWORACH CECHSZTYNU
}

\author{
XRMI measurements in Zechstein sediments
}

\author{
Wiesława ROMANIUK ${ }^{1}$ \\ ${ }^{1}$ Geofizyka Toruń S.A., ul. Chrobrego 50, 87-100 Toruń; \\ e-mail: wieslawa.romaniuk@geofizyka.pl
}

Treść: Pomiar XRMI bazuje na kontraście mikroopornościowym skał. Sonda jest nazywana przyrządem „o rozszerzonym zakresie”, ponieważ daje bardzo dobrej jakości obraz ściany otworu, nawet w formacjach o wysokiej oporności $(>2000 \Omega \cdot \mathrm{m})$ i przy stosowaniu zasolonych płuczek o relatywnie niskich opornościach $(<0,1 \Omega \cdot \mathrm{m})$. Dzięki dużej rozdzielczości pionowej pomiarów sonda ta daje możliwość interpretacji powierzchni warstwowania wraz z informacją o tym, w którym kierunku i pod jakim kątem są one nachylone oraz zidentyfikowania fałdów, uskoków i mikrouskoków, spękań, niezgodności kątowych. Na obrazach mikroopornościowych zaznaczają się również struktury powstałe w wyniku odwiercenia otworu: szczeliny indukowane, struktury wykruszeniowe typu breakouts, ślady świdra. Pomiary sondą XRMI mają wiele zastosowań w interpretacji strukturalnej i sedymentologicznej, mogą dostarczać również informacji o właściwościach mechanicznych górotworu, przydatnych zarówno w procesach wiercenia otworu, jak i podczas zabiegów szczelinowania.

Słowa kluczowe: obrazy mikroopornościowe, sonda XRMI, warstwy, szczeliny, breakouts, ewaporaty, cechsztyn

\begin{abstract}
The XRMI measurement relies on micro-resistance contrast of rocks. The system is called the "X-tended Range Micro Imager" because it gives a very good quality borehole wall images even in highly resistive formations $(>2000 \Omega \cdot \mathrm{m})$ and relatively low-resistance salty mud $(<0.1 \Omega \cdot \mathrm{m})$. Owing to a high vertical resolution of measurements, this tool allows for interpretation of bedding surfaces, with information about their dip angle and azimuth, as well as recognition of folds, faults and microfaults, fractures, and angular unconformities. The images also show structures resulting from well drilling: induced fractures, breakouts, or bit marks. XRMI measurements are applied in both structural and sedimentological interpretations, and they can give some geomechanical information helpful in borehole drilling and hydraulic fracturing.
\end{abstract}

Key words: microresistivity images, XRMI tool, beds, fractures, breakouts, evaporites, Zechstein 


\section{WSTĘP}

Wyznaczanie kąta i azymutu zapadania warstw w otworach wiertniczych (Jarzyna et al. 1997, Kiełt 2002) na podstawie kontrastu mikroopornościowy skał przy zastosowaniu sond elektrycznych (wykonywane od wielu już lat m.in. przez Geofizykę Toruń SA) ma długą historię. Kolejno udoskonalane przyrządy pozwalały na coraz dokładniejsze określenie tych parametrów. Jednym z najnowszych rozwiązań jest sonda XRMI (X-tended Range Micro Imager) umożliwiająca zobrazowanie ściany otworu dzięki przetworzeniu zarejestrowanych równocześnie na danej głębokości 150 pomiarów elektrycznych o wysokiej pionowej rozdzielczości, wynoszącej 0.2", czyli około $5 \mathrm{~mm}$, zarówno w odwiertach pionowych, jak i nachylonych (w tym horyzontalnych). W przypadku odwiertu o średnicy nominalnej 8.5", czyli $216 \mathrm{~mm}$, otrzymujemy obraz stanowiący odwzorowanie $67 \%$ powierzchni ściany otworu. Jest to wielkość wystarczająca do przeprowadzenia dokładnej interpretacji.

Sonda XRMI ma sześć ramion, które działają niezależnie, co ma duże znaczenie przy mierzeniu średnicy w otworze, w którym występują nieregularne wykruszenia czy wymycia.

Omawiana sonda została nazwana przyrządem „o rozszerzonym zakresie”, ponieważ daje bardzo dobrej jakości obraz ściany otworu, nawet w formacjach o wysokiej oporności (>2000 $\Omega \cdot \mathrm{m})$ i przy stosowaniu zasolonych płuczek o relatywnie niskich opornościach $(<0,1 \Omega \cdot \mathrm{m})$. Dzięki tej właściwości urządzenie znajduje zastosowanie przy badaniu utworów węglanowych cechsztynu. Używane są wtedy płuczki solne (Bielewicz 2009) charakteryzujące się niską opornością w stosunku do skały zbiornikowej, co wcześniej utrudniało, a czasem wręcz uniemożliwiało prawidłowy odczyt obrazu warstwowania czy obecności spękań.

\section{PRZYKLADY ZASTOSOWANIA POMIARÓW WYKONANYCH SONDĄ XRMI}

Na obrazach mikroopornościowych można obserwować różnorodne struktury zarówno naturalne, jak i indukowane (czyli powstałe w związku z procesem wiercenia otworu, np. szczeliny indukowane, struktury wykruszeniowe typu breakouts i ślady świdra, jak też w wyniku pobierania rdzeni) i określać ich położenie względem północy geograficznej. Jednym z podstawowych zastosowań pomiarów wykonywanych sondą XRMI jest określenie rzeczywistych kątów i kierunków zapadania warstw. Wyniki takich pomiarów są następnie wykorzystywane m.in. do interpretacji strukturalnej i sedymentologicznej. Dla wykonywania tej ostatniej istotna jest możliwość odróżnienia rodzajów warstwowania, np. horyzontalnego, ale również falistego czy oczkowego. Dla interpretacji strukturalnej niezbędne jest opisanie fałdów, uskoków i mikrouskoków oraz szczelin. Przy występowaniu odpowiedniego kontrastu oporności dobrze widoczne są soczewki. Na obrazach mikroopornościowych, szczególnie w szczelinach, często dostrzec można mineralizację. Wyraźnie widoczne są brekcje jak również zlepieńce. Omawiane pomiary umożliwiają wyznaczenie niezgodności kątowych oraz z pewnym przybliżeniem deformacji w utworach nieskonsolidowanych. W niektórych przypadkach możliwe jest ustalenie kierunków paleotransportu.

Przy określeniu własności zbiornikowych pomocne jest odróżnienie typów porowatości w węglanach, na przykład kawernistej, fenestralnej czy szczelinowej. 
Niezmiernie ważna jest możliwość wyznaczenia szczelin wraz z określeniem ich orientacji (Dadlez \& Jaroszewski 1994). Wtórna porowatość w postaci spękań może wpłynąć na polepszenie parametrów złożowych (wzrost przepuszczalności). Z drugiej strony ich obecność może być niekorzystna, gdy zaistnieją warunki do migracji wody do otworu. $\mathrm{Na}$ obrazach mikroopornościowych szczeliny zaznaczają się jako struktury ciągłe lub widoczne są jedynie ich fragmenty. W odpowiednich warunkach możliwe jest odróżnienie charakteru spękań - otwartych, zamkniętych lub częściowo zabliźnionych. Kolejnym ważnym i zarazem niełatwym zadaniem interpretacyjnym jest odróżnienie szczelin naturalnych od indukowanych (powstałych w wyniku odwiercenia otworu), co dostarcza ważnych informacji przy zabiegach szczelinowania. Widoczne są również ślady świdra oraz miejsca, w których zostało wykonane rdzeniowanie boczne.

Do wykonania prawidłowej interpretacji strukturalnej niezbędne jest wyznaczenie położenia przewierconych uskoków czy mikrouskoków oraz określenie ich rodzajów. Zdarza się, że nie można wyznaczyć powierzchni uskokowej, a jedynie strefę zmienioną tektonicznie, często zzaburzonymi upadami i obecnością brekcji, która zwykle jest dobrze widoczna na obrazach mikroopornościowych.

Bardzo dobre wyniki dają pomiary sondą XRMI wykonywane w utworach węglanowych. Wydzielić w nich można różnorodne typy warstwowania, powierzchnie erozyjne, szczeliny zarówno otwarte jak i zabliźnione, różne rodzaje porowatości, uskoki i mikrouskoki. Niejednokrotnie zaznacza się obecność szwów stylolitowych. Zaobserwowano bardzo dobre odwzorowanie obrazów mikroopornościowych względem pobranych rdzeni.

Figura 1A przedstawia warstwowane pod kątem $1-9^{\circ} \mathrm{w}$ kierunkach SW, SSW, S, SSE, SE i NNE utwory dolomitu głównego z licznymi, fragmentarycznie zaznaczającymi się spękaniami naturalnymi nachylonymi pod kątem $32-82^{\circ} \mathrm{w}$ kierunkach NE, NNE, SE, SSE, NW i SW. Przykładową warstwę wskazują czarne strzałki, różowe natomiast oznaczają fragmenty niektórych spękań.

Pomiary wykonywane sondą XRMI dają bardzo dobre rezultaty w węglanach, piaskowcach czy utworach zailonych. Również w kompleksach ewaporatowych można niejednokrotnie zaobserwować interesujące struktury. Na przykład figura 1B prezentuje anhydryt Werra nieregularnie warstwowany substancją ilastą, w dolnej części poziomu pojawiają się anhydryty gruzłowe. Na figurze 1C obrazującej utwory anhydrytu głównego bardzo wyraźnie widoczna jest regularna laminacja materiałem ilastym pod kątem $11-19^{\circ} \mathrm{w}$ kierunku NW. Czarnymi strzałkami pokazano przykładową warstwę. Wydawać by się mogło, że w przypadku przewarstwień anhydrytowych w solach na profilowaniach mikrooporności nie będzie widać istotnych różnic z powodu zbyt małego zróżnicowania wartości oporności tych skał. Jednakże w niektórych przypadkach praktyka pokazuje, iż na obrazie zarówno statycznym jak i dynamicznym (Fig. 1D), obserwuje się warstewki anhydrytu (tu o miąższości około $2 \mathrm{~cm}$ ). Jest to jednak raczej wynikiem wymywania soli i wejścia w powstałe kawerny zasolonej płuczki wiertniczej, która dobrze kontrastuje z wysokooporowymi anhydrytami. Warstwy zapadają pod kątem $10-17^{\circ} \mathrm{w}$ kierunkach WNW, W i WSW. Na przedstawionych obrazach mikroopornościowych mają one jasny kolor, a jedna z nich, jako przykładowa, została wskazana zielonymi strzałkami. 


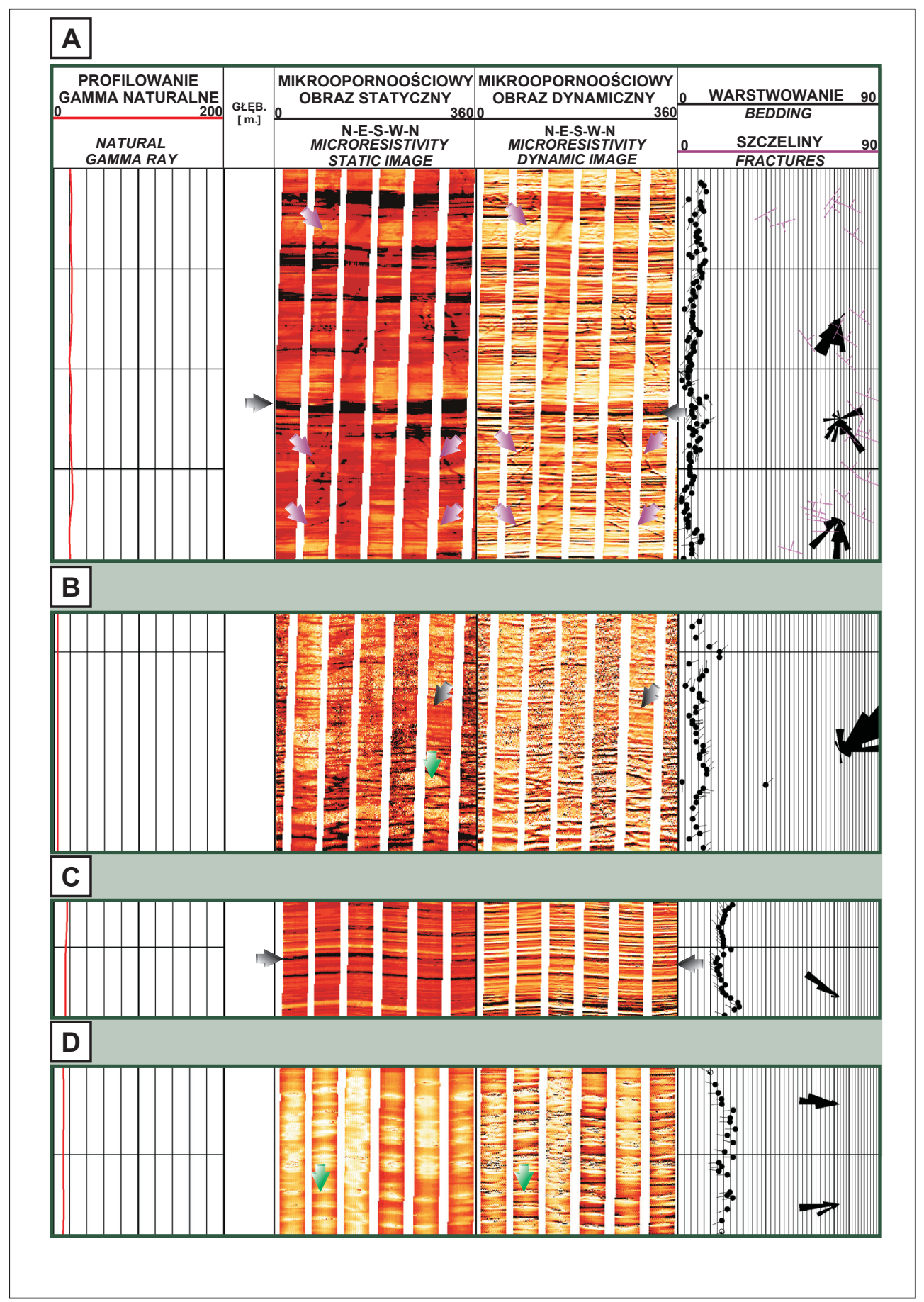




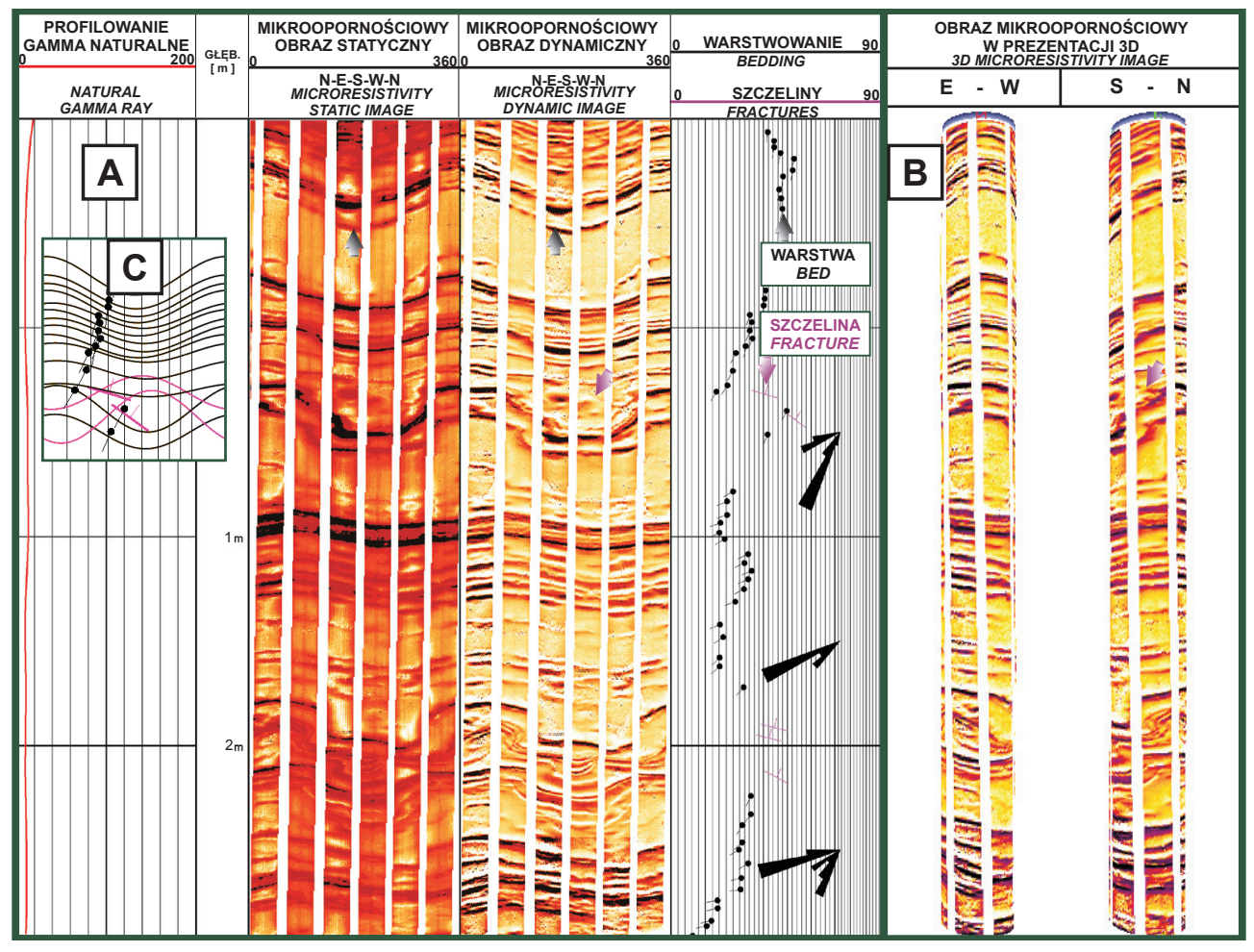

Fig. 2. Przykład soli z przewarstwieniami anhydrytu i laminami ilastymi: A) laminy ilaste (ciemne kolory, niższa oporność) w solach z przewarstwieniami anhydrytu (jasne kolory, wyższa oporność); czarna strzałka wskazuje przykładową laminę ilastą, różowa strzałka szczelinę; B) prezentacja 3D (pierwszy od lewej ,pseudordzeń” o kierunkach E-W, następny jest odwrócony o $90^{\circ}$, kierunki S-N); różowa strzałka wskazuje przykładową szczelinę; C) sinusoidalne odwzorowanie warstwowania i szczelin

Fig. 2. Example of salt with anhydrite bedding and clay lamination: A) clay lamination (dark colours, lower resistivity) in salts with anhydrite bedding (light colours, higher resistivity); black arrow shows an example of clay laminae, pink arrow - fracture; B) 3D presentation (first from left "pseudo-core" with $\mathrm{E}-\mathrm{W}$ directions, next $90^{\circ}$ rotated, S-N directions); pink arrow shows an example of fracture;

C) sinusoidal mapping of bedding and fractures

Fig. 1. Prezentacja wyników XRMI: A) warstwowanie i szczeliny w utworach węglanowych cechsztynu; czarne strzałki wskazują przykładową warstwę, różowe - fragmenty szczelin; B) warstwowanie (czarne strzałki) w anhydrycie cyklotemu Werry, w dolnej części rysunku widoczny anhydryt gruzłowy (zielona strzałka); C) warstwowane utwory anhydrytu cyklotemu Leine; czarne strzałki wskazują przykładową warstwę; D) warstwowanie anhydrytem (zielone strzałki) w solach

Fig. 1. XRMI results presentation: A) bedding and fractures in Zechstein carbonate sediments. Black arrows show an example of bed, pink - parts of fractures; B) bedding (black arrows) in Werra anhydrite, nodular anhydrite (green arrow) in lower part of picture; C) bedding in Leine anhydrite; black arrows show an example of bed; D) anhydrite layers (green arrows) in salts 


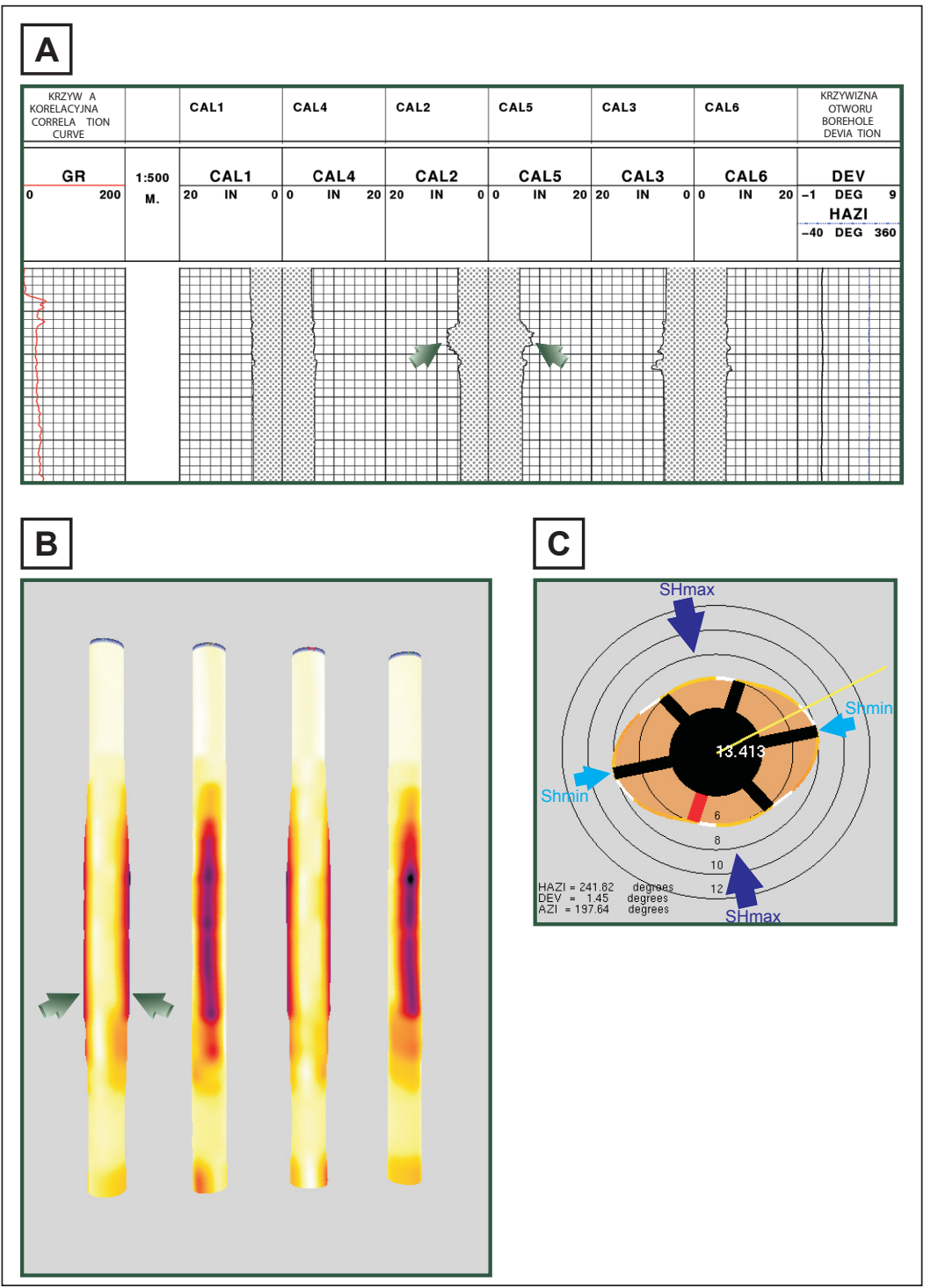

Fig. 3. Geometria otworu: A) prezentacja geometrii otworu w postaci zestawionych par średnic otworu mierzonych przez przeciwległe ramiona sondy XRMI; strzałki pokazują struktury wykruszeniowe (breakouts); B) przestrzenne przedstawienie struktur wykruszeniowych (breakouts); ciemniejsze kolory pokazują powiększenie średnicy; C) przekrój poprzeczny otworu z naniesionymi kierunkami najmniejszych (Shmin) i największych (SHmax) naprężeń horyzontalnych

Fig. 3. Borehole geometry: A) borehole geometry presentation as a sets of pairs of borehole diameters measured by opposite pads of XRMI tool; arrows show breakouts; B) 3D presentation of breakouts (darker colours show diameter enlargement); C) transversal crossection of borehole with minimal (Shmin) and maximal (SHmax) horizontal stress directions 
Na figurze 2 przedstawiony został fragment kompleksu soli starszej, wykształcony w tym przypadku jako przewarstwienia soli i anhydrytów z laminacją materiałem ilastym. Struktury zaznaczone jako szczeliny są prawie niewidoczne i stanowią właściwie zabliźnione miejsca po nich. Jako przykład na obrazach mikroopornościowych fragment takiego spękania został wskazany różowymi strzałkami. Ich wcześniejszą obecność sugeruje głównie podgięcie lamin ilastych. Ponieważ nie są to czyste sole, ale występują w nich niewielkie miąższościowo przewarstwienia anhydrytu i laminy ilaste (jedną z nich przykładowo wskazano czarnymi strzałkami), mogły powstać spękania w sztywniejszym materiale, które zostały następnie zabliźnione solą.

Osobnym zagadnieniem jest możliwość znalezienia na podstawie pomiaru omawianą sondą struktur wykruszeniowych zwanych breakouts (Fig. 3A). Są one symetrycznymi (Fig. 3B), umiejscowionymi co $180^{\circ}$ na ścianie otworu wykruszeniami. Odgrywają niebagatelną rolę w geomechanice przy wyznaczaniu kierunków minimalnych naprężeń horyzontalnych górotworu (Prensky 1992).

Wspomniane wykruszenia zaznaczają się wyraźnie na zestawieniu par wyników pomiarów średnic zarejestrowanych na przeciwległych ramionach sondy. Z ich występowaniem związany jest owalny kształt przekroju poprzecznego otworu, tu z naniesionymi kierunkami najmniejszych (Shmin) i największych (SHmax) naprężeń horyzontalnych (Fig. 3C). W lewym dolnym rogu rysunku widoczne są dane dotyczące kierunku (HAZI) i wielkości odchylenia otworu od pionu (DEV) (tu rozpatrywany jest przypadek otworu niemalże pionowego) oraz azymutu pierwszego ramienia sondy (AZI).

Ponieważ omawiane obrazy mikroopornościowe charakteryzują się obecnością dużej ilości szczegółowych struktur, widocznych również na pobieranych wcześniej rdzeniach z danego otworu, można je zatem porównywać (Adams et al. 1990, Amer et al. 2009, Chakravorty et al. 2009). Przydatne jest to m.in. do ustalenia orientacji pobranego rdzenia względem północy geograficznej. Ułatwieniem dla interpretatora są dostępne prezentacje pomiarów oporności nie tylko w projekcji 2D, ale również w 3D, dzięki opcji tworzenia pseudordzenia mikroopornościowego.

Taka procedura może stanowić istotne uzupełnienie badań w przypadku pobierania rdzeni w otworach krzywionych. Zapadanie warstw na rdzeniu wiertniczym będzie się wtedy charakteryzować swego rodzaju ,pozornym” nachyleniem, w zależności od tego, pod jakim kątem i w jakim kierunku został skrzywiony otwór w stosunku do przewierconych warstw. W wyniku interpretacji pomiarów XRMI otrzymujemy rzeczywiste kąty i kierunki zapadania warstw lub szczelin. Nie bez znaczenia jest również to, że ślady poboru rdzeni bocznych są dość łatwe do zaobserwowania na obrazach mikroopornościowych.

\section{PREZENTACJA GRAFICZNA}

Aby ułatwić odczytywanie danych z figur zaprezentowanych w niniejszym artykule, poniżej zamieszczono krótki opis sposobu graficznej formy prezentacji wyników interpretacji. 


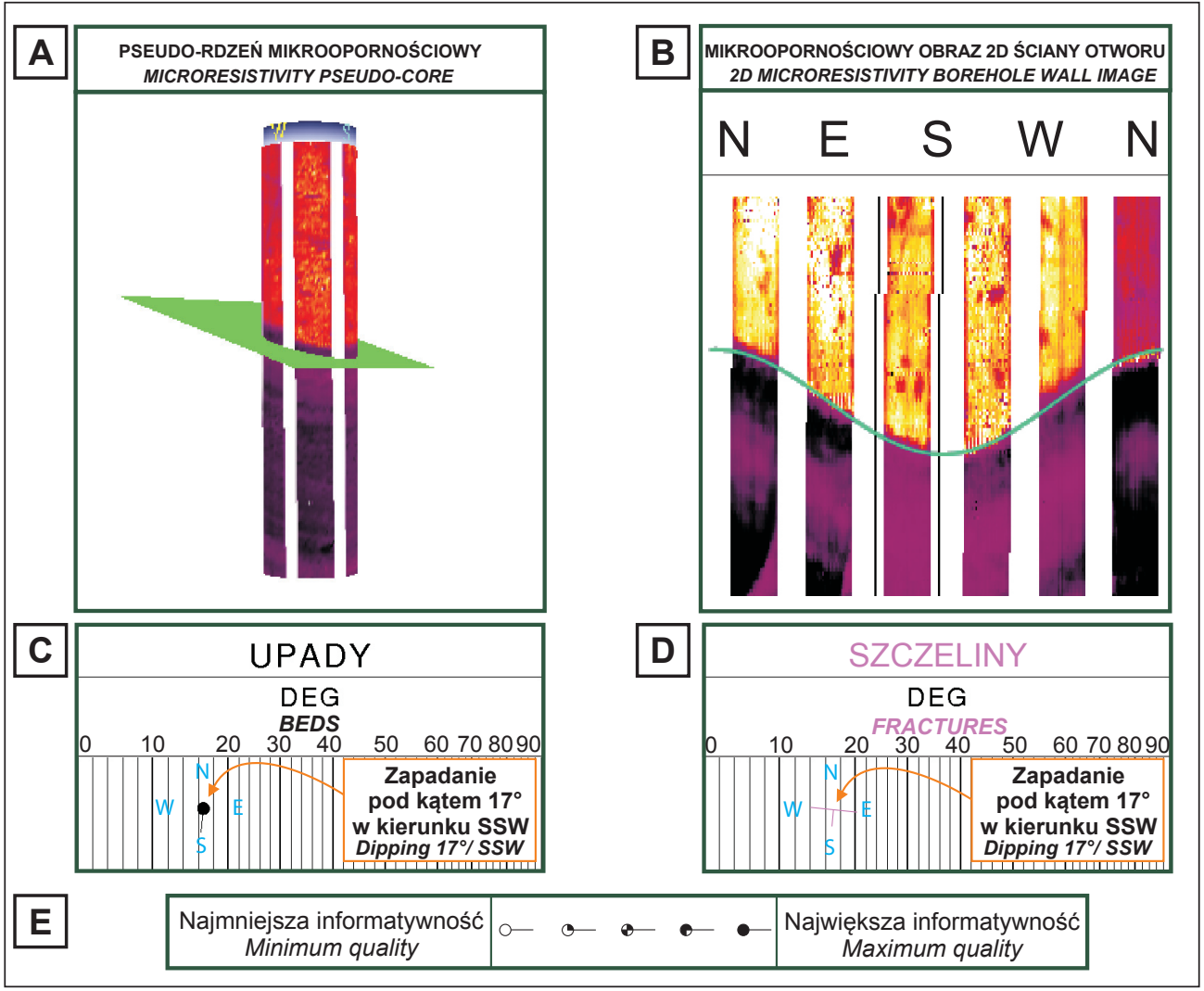

Fig. 4. Rodzaje prezentacji graficznej: A) prezentacja 3D obrazu mikroopornościowego (pseudordzeń) oraz płaszczyzny pokazującej zapadanie warstwy; B) obraz mikroopornościowy oraz warstwowanie przedstawione jako sinusoida; C) prezentacja graficzna płaszczyzny warstwowania; D) prezentacja graficzna szczeliny; E) informatywność obrazu wektorowego

Fig. 4. Types of graphic presentation: A) 3D presentation of microresistivity pseudo-core and plane showing the direction in which the bed is dipping; B) microresistivity image and bedding showed as a sinusoid; C) graphical presentation of bedding plane; D) graphical presentation of fracture; E) quality of vector plot

Na figurze 4A przedstawiono sposób obrazowania powierzchni geologicznych za pomocą płaszczyzn najlepiej im odpowiadających. Jest to w części przypadków pewne matematyczne przybliżenie rzeczywistej sytuacji (np. w przypadku deformacji warstwowania w utworach nieskonsolidowanych), ale niedogodność ta została maksymalnie ograniczona dzięki temu, że płaszczyzny te nie są obliczane jedynie przez program, ale interpretator może własnoręcznie je wyznaczyć. Zazwyczaj jest to niezbędne, gdyż oprogramowanie nie zapewnia automatycznego odróżnienia warstw od szczelin. W prezentacji 2D (Fig. 4B) płaszczyzna jest zobrazowana na podstawie obrazu mikroopornościowego w postaci sinusoidy, 
z której parametrów wyliczany jest kąt i kierunek zapadania danej struktury. Informacje te są przedstawiane na wykresie wektorowym za pomocą symboli. W przypadku warstwowania (Fig. 4C) kółko oznacza wartość kąta upadu odczytywaną w skali 0-90, krótka kreska natomiast - jego azymut (tu poszczególne kierunki zostały wyróżnione kolorem niebieskim). W graficznej prezentacji szczeliny (Fig. 4D) krótsza kreska wyznacza kierunek zapadania (na podobnej zasadzie jak w przypadku opisanym powyżej), dłuższa natomiast określa jej rozciągłość. Wartość kąta, pod jakim zapada szczelina, odczytywaną w skali $0-90^{\circ}$, wyznacza środek symbolu. W obrazowaniu uwzględniany jest jeszcze parametr zwany jakością odnoszący się do stopnia informatywności uzyskanych wyników (Fig. 4E).

Obraz ściany otworu jest otrzymywany w efekcie przetworzenia wyników pomiarów mikrooporności o wysokiej pionowej rozdzielczości (oczywiście przy uwzględnieniu niezbędnych parametrów, takich jak m.in. wielkość średnicy, ułożenie sondy w otworze względem północy magnetycznej czy też kąt i azymut odchylenia osi otworu od pionu). Obrazy o filtracji statycznej i dynamicznej różnią się od siebie, lecz każdy z nich ma swoje zastosowanie. Ten pierwszy, przy którego tworzeniu brane są pod uwagę wartości mikrooporności w obrębie całego interpretowanego interwału, dobrze oddaje ich relatywne różnice. Może on jednak nie uwidaczniać niektórych szczegółów. W celu uzyskania obrazu dynamicznego wprowadza się filtrację umożliwiającą wyraźniejsze odzwierciedlenie detali, często słabo widocznych czy wręcz niedostrzegalnych na obrazie statycznym. Procedura ta powoduje zarazem to, że można sugerować się relatywną zmianą wartości (barw), ale nie należy odnosić jej do całego rozważanego interwału pomiarowego.

\section{PODSUMOWANIE}

Pomiary sondą XRMI mają wiele zastosowań w interpretacji strukturalnej i sedymentologicznej. Pozwalają na wyznaczenie m.in. kątów i kierunków zapadania warstw oraz szczelin, jak również uskoków, mikrouskoków, fałdów, niezgodności kątowych oraz powierzchni erozyjnych. Umożliwiają identyfikację struktur powstałych w wyniku procesu odwiercania otworu, czyli na przykład szczelin indukowanych czy struktur wykruszeniowych typu breakouts mających zastosowanie do wyznaczania kierunków minimalnych naprężeń horyzontalnych górotworu.

Z pomiarów uzyskujemy informacje o stopniu i kształcie skawernowania ściany, jak też miejscach zaciskania otworu oraz o kącie i azymucie jego odchylenia od pionu.

\section{LITERATURA}

Adams J., Bourke L. \& Buck S., 1990. Integrating Formation MicroScanner Images and Cores. Oilfield Review, 2, 1, 52-64.

Amer A., Contreiras K., Cardoso E., Rueda M. \& Lopes A., 2009. An integrated study to understand the effect of anhydrite on wells drilled near fault system in Pinda Formation, offshore Angola. SPWLA 50 th Annual Logging Symposium, 2-24 June 2009, The Woodlands, Texas, 1-12. 
Bielewicz D., 2009. Ptyny wiertnicze. Wydawnictwa AGH, Kraków.

Chakravorty R., Gopala Rao V., Kumar R. \& Roy S., 2009. Extended Range Micro-Imager $(\mathrm{XRMI})^{\mathrm{TM}}$ Applications in Coal Environment. Proceedings of $2^{\text {nd }}$ SPWLA-India Symposium: Innovations in Petrophysical Evaluation of Unconventional Reservoirs, Grand Hyatt, Mumbai, India November 19-20, 2009, 1-22.

Dadlez R. \& Jaroszewski W., 1994. Tektonika. Wydawnictwo Naukowe PWN, Warszawa.

Jarzyna J., Bała M. \& Zorski T., 1997. Metody geofizyki otworowej: pomiary i interpretacja. Wydawnictwa AGH, Kraków.

Kiełt M., 2002. Geofizyka wiertnicza w poszukiwaniach węglowodorów: strukturalne i sedymentologiczne zastosowanie otworowych profilowań geofizycznych. T. 1. Wydawnictwo Adam Marszałek, Toruń.

Prensky S., 1992. Borehole breakouts and in-situ rock stress - a review. The Log Analyst, 33, 3, 304-312. 